\title{
THE QUESTIONABLE TESTAMENTARY GIFT TO CHARITY: A SUGGESTED APPROACH TO JUDICIAL DECISION*
}

\author{
ROBERT J. LYNN†
}

$\mathrm{A}^{\mathrm{n}}$

TESTATOR who desires to leave property to a public purpose occasionally devises or bequeaths it to his government. I More frequently he chooses to channel wealth through the distributive machinery known to the law as "charity." 2

If he uses dispositive language sanctioned by precedent, he may with assurance be either general ${ }^{3}$ or specific ${ }^{4}$ in making his gift. If attacked on the ground that it is not "charitable," that is, not in the public interest, the devise or bequest ordinarily will be upheld.

If, on the other hand, the language of the instrument falls short of the conventional, the will requires "interpretation" or "construction" or both. When these processes are invoked in the context of the charitable gift, we encounter judicial utterances commonplace in testamentary cases: The intention of the testator is the polar star of construction. 5 Intention is determined

* I want to express my gratitude to Alan S. Kerxton and James W. Carpenter for their valuable research assistance.

† Professor of Law, The Ohio State University Law School.

1 As did Mr. Justice Holmes. "Without accompanying explanation, he [Holmes] left the bulk of his substantial estate to the nation, the largest unrestricted gift ever made to it." Frankfurter, Oliver Wendell Holmes, in 21 Dictionary OF AMERICAN BIOGRAPHY 417, 427 (1944).

2 The amount of wealth devoted to charitable purposes in the United States is not known. Vestal, Critical Evaluation of the Charitable Trust as a Giving Device, 1957 WASH. U.L.Q. 195, 198 n.14.

See 108 CoNG. REC. 15943 (daily ed. Aug. 20, 1962) (remarks of Congressman Patman): "At the close of 1960, these 524 [tax-exempt] foundations had aggregate assets worth no less than $\$ 10,239,350,627 \ldots$

"Certain foundations have acquired immense power and positions in our economy.

"At the close of 1960 , the net worth of the 524 foundations- $\$ 9,810,467,852$-was 23 percent greater than the ... capital funds ... of the Nation's 50 biggest commercial banks.

"Their net worth was also 26 percent greater than the ... invested capital ... of the Nation's 50 largest merchandising firms."

34 SCOTT, TRusTs § 368 (2d ed. 1956) [hereinafter cited as ScoTT].

4 E.g., Tollinger Estate, 349 Pa. 393, 37 A.2d 500 (1944), upheld as charitable a bequest of $\$ 5,000$ to a bank in trust to pay the income "to the Treasurer of the Men's Club connected with the Church of the Good Samaritan. ... The income ... to be expended ... exclusively for food for banquets which they may have at any regular or special meeting . ..." Id. at 394-95, 37 A.2d at 501.

5 E.g., Little Estate, 403 Pa. 247, 259, 168 A.2d 738, 745 (1961) (concurring opinion). 
from the four corners of the instrument, ${ }^{6}$ from the circumstances surrounding the testator at the time of execution 7 and from putting one's self in the testator's armchair. ${ }^{8}$ The inadequacy of such expressions will not be pursued here. Rather, the purpose of this article is (1) to suggest factors that do or should influence decision when the effectiveness of a gift arguably charitable hangs in the balance, and (2) to demonstrate that reformation of the charitable trust is in part achievable within the framework of traditional legal doctrine through more intensive judicial consideration of all relevant factors when the validity of a gift arguably charitable is before the court.

I

Louis Little died testate in 1956 survived by two sisters and one brother. He had never married. He disposed of his residuary estate of approximately $1,000,000$ dollars by the following testamentary language:

The balance of my Estate, real, personal and mixed is to be deposited, after payment of taxes in a fund. From this Fund there must be a suitable memorial for my saintly brother Hyman \& my wonderful parents Lizzie \& Jacob Little. I entreat my executors to seek advise [sic] from good friend Leon Falk as to the nature of the memorials. However I do not want this money to be governed or used by social workers in any manner whatsoever as I have seen to [sic] much abuse, extravagance, duplication and more, by them. 9

At issue was whether or not Louis Little had created a valid charitable trust despite his vague, imprecise language. If he succeeded, clearly the function of the trust would be general, except for the restriction on disposition by social workers; for here there was no direction that all expenditures be made for any of the myriad particular purposes 10 that from time to time have qualified as "charitable." 1948).

6 E.g., Wilber v. Asbury Park Nat'l Bank, 142 N.J. Eq. 99, 122, 59 A.2d 570, 582 (Ch.

7 E.g., First Nat'l Bank v. Stevenson, 293 S.W.2d 362, 366 (Mo. Sup. Ct. 1956).

8 "Let us therefore place ourselves in testator's armchair and examine more closely testator's relationship to Cushing Academy." Hoffman Estate, 15 Pa. D. \& C.2d 295, 303 (Orphans' Ct. 1958). Some courts are remarkably adept at performing this feat. "We are convinced that when he [the testator, in 1870] executed his will on the day before he died, he was imbued with a deep charitable intent, and that he intended all of his worldly goods and effects to be devoted forever to the relief of indigent seamen, not only of the class to which he belonged, but to all classes of indigent seamen." Petition of Pierce, $153 \mathrm{Me}$. 180, 200, 136 A.2d 510, 521 (1957). "I would say that it is not enough to sit in the testator's armchair. One must enter into his heart via the words spoken by him in perhaps the most solemn moment in man's consciousness-that one moment when one contemplates the long road into eternity on the way to meeting with those who have gone before." Little Estate, $403 \mathrm{~Pa} .247,260,168$ A.2d 738, 745 (1961) (concurring opinion).

9 Little Estate, 403 Pa. 247, 250, 168 A.2d 738, 740 (1961).

${ }_{10}$ E.g., Connecticut College v. United States, 276 F.2d 491 (D.C. Cir. 1960) (to erect a building on the Plain at West Point); Petition of Pierce, 153 Me. 180, 136 A.2d 510 (1957) (to found a home for indigent seamen). 
A majority of the Supreme Court of Pennsylvania had little difficulty in finding that Louis Little created a valid charitable trust-so little difficulty, in fact, that the portion of the opinion by Chief Justice Jones dealing with the validity of the residuary gift consists almost exclusively of quotations from the opinion of the auditing judge, who, in sustaining the gift, had relied heavily on Leon Falk's activities as a well-known philanthropist. That Louis Little was a lawyer and could have made his intention to give to charity crystal clear by using time-worn customary language was not thought to be critical by the court.11

Recent American cases considering the validity of gifts arguably charitable reflect little of the sporadic judicial antipathy toward charity characteristic of the nineteenth century.12 Charity has long since come into its own. In the last half of the twentieth century the more relevant inquiry may well be this: How palpably bad must an intended gift be before a court will characterize it as bad?

For illustrative purposes, consider In re Estate of Small.13 Dr. W.B. Small died testate in 1939 survived by his widow and two nieces. His will directed that upon the death of his widow the trustees of his residuary estate distribute the income thereof

to such persons and for such purposes as they may feel is directed by God the Father, Jesus Christ the Son, and Holy Spirit, and as they believe would be acceptable to me and meet my approval....

By way of explanation it is my desire that any disbursements made under this paragraph shall be made to persons who believe in the fundamental principles of the Christian Religion and in the Bible and who are endeavoring to promulgate the same.14

A majority of the Iowa Supreme Court upheld this disposition as a valid charitable gift. The long-term implications of such a result are suggested in the brief dissenting opinion of Chief Justice Smith:

Here, trustees are named who presumably knew Doctor Small's wishes and to whose discretion he was willing to commit the selection of purposes and beneficiaries. We are asked not merely to hold this sufficient for the immediate present but to confide to future trustees selected by future trus-

11 Justice Benjamin R. Jones in dissent succinctly put the case against validity: "Mr. Little may have intended to create a trust for charitable purposes . . . but . . . the language employed by him fails to demonstrate such intent. Nor do I feel that such intent can be gleaned from a review of the personal life and expressed affections of the decedent .... The conclusion arrived at by the majority of this Court rewrites paragraph fifteen [of the will] to accomplish what it believes Mr. Little intended. Absent language in this will clearly expressive of such an intent, I stand opposed to incorporating into paragraph fifteen what $\mathrm{Mr}$. Little may have intended." Little Estate, 403 Pa. 247, 262, 168 A.2d 738, 743 (1961).

12 See Ames, The Failure of the "Tilden Trust," 5 Harv. L. Rev. 389 (1892).

13244 Iowa 1209, 58 N.W.2d 477 (1953).

$14 \mathrm{Id}$. at 1214,58 N.W.2d at 479. 
tees in succession, "permanently and forever," the selection of such beneficiaries and the determination of such purposes to be served "as they (trustees) may feel is [sic] directed by God . . . and as they believe would be acceptable to" Doctor Small.

I cannot consent to the imposition of this burden upon the court for all time to come....15

In other words, when the validity of the gift is in doubt, attributes of the charitable trust that in the context of this particular bequest are repellent should invalidate the intended gift. The standard for periodic distribution set by the testator is too vague for succeeding generations to cope with effectively, and, on balance, his wishes ought not to be indulged.

The resolution of cases like Little Estate and In re Estate of Small customarily proceeds by asking whether the testator intended to make a charitable gift. That is, taking account of not only his words, but also all relevant circumstances surrounding the making of the attempted gift, and consulting authoritative definitions of "charity" and those precedents deemed appropriate, do we find the devise or bequest sufficiently like those approved heretofore to warrant validation in this instance?

Invoking definitions of charity and examining precedents are appropriate to the task at hand, but such limited procedures tend to invite a wrong decision in too many cases. The charitable gift is sanctioned because it encourages expenditure of private funds for functions commonly supported by public funds. In short, the charitable gift is indulged because it is in the public interest. Therefore, determining whether the questionable gift qualifies as charitable necessarily includes a projection of the gift in operation, for in no other way can we be as certain that the gift is truly in the public interest. Tested in this way, the result reached in Little Estate is defensible if it is assumed that the case was properly handled initially with respect to the more abstract question

15 Id. at 1243, 58 N.W.2d at 494-95. But cf. Hoenig v. Newmark, 306 S.W.2d 838 (Ky. Ct. App. 1957), where the testatrix left her residuary estate in trust "with the express understanding that my Trustees shall be permitted, in their sole discretion, to distribute the same for me ... to such educational or charitable institutions or to such individual or individuals as, in their sole discretion, they may determine to be worthy, with the suggestion ... that [they] ... carefully investigate the schools in the backwoods and mountains of Kentucky lending aid to underprivileged children and needy students." Id. at 839 . The Kentucky court held that the gift failed: "The clause in question is not only uncertain about the particular charity testatrix intended to benefit, but it leaves our minds in doubt whether the testatrix intended to limit her bequest to a charitable use. It is our opinion that the attempted bequest amounts to nothing more than a power of attorney for the trustees to make a bequest in behalf of the testatrix...." Id. at 840 .

Although the issues in Little Estate and In re Estate of Small are comparable, they are not identical. In the former, the intention of the testator to use his wealth to create a memorial to his family is evident from his language; in the latter, the intention of the testator to use his wealth to support periodic distributions of money to selected individuals is clear. In Little Estate, finding a charitable intention of any kind is the problem, whereas in In re Estate of Small, squaring expressed intention with traditional notions of intention to promote religion is the difficulty. 
of "intention." For in Little Estate the testator put only minimal restrictions on permissible expenditures. On the other hand, the questionable bequest of In re Estate of Small was wrongly validated in view of the potential difficulty in administering the gift through time.

II

When projecting the questionable gift to appraise its future public utility, what discernible characteristics of the contemporary charitable trust should be in the mind of the court seeking the best decision possible within the framework of current doctrine and practices? Distinctive attributes of the charitable trust that in the abstract make it attractive to donors may in practice frustrate the intentions of the testator and deprive the public of the continuing benefit of the gift. That persons now unborn may enjoy his bounty appeals to the prospective donor, and that the attorney general and the judiciary are charged with the continuing obligation of enforcing his intentions encourages him to make a charitable gift. Are his expectations well founded? Even so friendly a critic of the charitable trust as Professor Simes concedes that often they are not. 16

\section{A. Perpetual Life and Continuing Supervision}

Although an occasional donor will limit the duration of a charitable trust, ${ }^{17}$ the desire to be thought generous over the longest possible span of time is natural in our culture. That it should be indulged is not surprising. If the public interest in a contemplated gift is thought sufficient to qualify it as "charitable," it need only vest within the period of the Rule Against Perpetuities. 18 Thereafter it may endure forever, and some English charitable gifts are

16 Simes, Public Policy and the Dead HaNd 110-32 (1955). In Anderson v. Ryland, 232 Ark. 335, 336 S.W.2d 52 (1960), the Supreme Court of Arkansas in approving a sale of trust property despite a restraint on alienation in the deed of trust executed by the settlor, noted that the trustees could select their own successors. Id. at 337, n.1, $336 \mathrm{~S}$.W.2d at 53, n.1.

In the Matter of Sousa, 26 Misc. 2d 474, 203 N.Y.S.2d 3 (Sup. Ct. 1960), Justice Olliffe confirmed the power of a charitable corporation to change its method of electing directors so that the board of directors could be self-perpetuating.

17 As did Julius Rosenwald, who provided that capital and income of the Julius Rosenwald Fund be spent within twenty-five years after his death. "By adopting a policy of using the Fund within this generation, we may avoid those tendencies toward bureaucracy and a formal or perfunctory attitude toward the work which almost inevitably develop in organizations which prolong their existence indefinitely. Coming generations can be relied upon to provide for their own needs as they arise." Letter from Julius Rosenwald to Trustees, Julius Rosenwald Fund, April 30, 1928, in ANDREWs, LEGAL INSTRUMENTS OF FOUNDATIONS 272 (1958).

The Max C. Fleischmann Foundation of Nevada, with assets of $\$ 75,000,000$ must be liquidated by July 4, 1980. Foundation News, Sept. 1960, p. 9. See also Hoffman Estate, 15 Pa. D. \& C.2d 295, 297 (Orphans' Ct. 1958).

18 Leach, Perpetuities in a Nutshell, 51 Harv. L. Rev. 638, 668 (1938); Lynn \& Van Doren, Applying the Rule Against Perpetuities to Remainders and Executory Interests: Orthodox Doctrine and Modern Cases, 27 U. CrI. L. REv. 436 (1960). 
disposed to do precisely that.19 A directed accumulation of income for an indefinite time is permissible, subject only to judicial control.20

The distinctive features of perpetual life are a mixture of good and bad. The foundations with great resources and minimal restrictions on expenditures can take the long view and can "pioneer." But they require a continuing supervision that they do not now receive and are not likely to receive in the foreseeable future. 21 The fund, large or small, of highly restricted purpose cannot explore, and that disability makes adequate supervision more critical if waste is to be avoided.

Pruner Estate22 dramatically demonstrates the imperfections of perpetual life and the illusory nature of judicial supervision of the highly restricted gift. There the testator, who died in 1904, left property in trust "for a Home for Friendless Children from the Towns of Tyrone and Bellefonte" which was duly established. From 1918 until 1935 there were fifteen children in the home. Commencing in April, 1942, there were no children in the home for two years. From May, 1944, until February, 1945, there were but two. From April, 1945, to May, 1949, there was but one. From May, 1949, to June, 1960, there were none. The Supreme Court of Pennsylvania put it this way:

The Board of Managers of the Home notified not only the Boroughs of Tyrone and Bellefonte, but also the Salvation Army, the Council of Churches in Tyrone and Bellefonte, the Welfare Agencies of those counties, and persons and organizations who are caring for and looking after friendless or homeless children, of the Home's facilities. In spite of the efforts of the Board of Managers to secure friendless children for the Home, no children have been in the Home for 10 years. ${ }^{23}$

Heirs to an alleged reversionary interest sought the property on the theory that the purpose of the trust had failed. The Supreme Court held that the reversionary interest was bad under the Rule Against Perpetuities. Cy pres could not be applied because there was an explicit testamentary disposition of corpus should the trust fail. The interest of the Home being determinable, there was a resulting trust for the heirs of the testator that took effect automatically.

The result attained in Pruner Estate is defensible; but what ought not to be overlooked is the failure of the trustees to seek instructions when the ineffectiveness of the gift became obvious. When the effective life of an arguably charitable trust of highly restricted purpose has not been fixed by the testator, the fact that it might endure forever should be considered in determining whether or not, on balance, it is in the public interest.

19 See Jordan, Phil.anthropy in ENGLANd 1480-1660 123 (1959).

204 SCOTT $\S 401.9$.

21 Karst, The Efficiency of the Charitable Dollar: An Unfulfilled State Responsibility, 73 HARV. L. REv. 433 (1960).

22400 Pa. 629,162 A.2d $626(1960) . \quad 23$ Id. at 633,162 A.2d at 629. 


\section{B. Accumulation and Termination}

The failure of the main purpose of a charitable trust does not necessarily result in its termination; as Franklin Foundation v. Attorney General24 demonstrates. Benjamin Franklin, the American patriot, in 1790 left about 4,500 dollars in trust to Boston, Massachusetts, to be lent at interest to "young married Artificers" to assist them in setting up business. At the end of one hundred years the fund was to be spent in part for "public works" and the balance lent out at interest for the same purpose for another one hundred years and then given to the City of Boston and the State of Massachusetts. The operation of the fund is described by the Supreme Court of Massachusetts as follows: "For the first few years of the operation of the fund substantially all of it was kept loaned to artificers. Thereafter until 1811 the number of properly qualified applicants progressively decreased. By 1836 less than six per cent of the fund was so employed, and by 1866 less than one per cent. No loans have been made since 1886."2s

The required disposition of corpus and accumulated income one hundred years after Franklin's death reduced the loan fund to about 100,000 dollars. In 1959 the market value of the fund was 1,578,098 dollars. Finding it impossible to lend as prescribed by Franklin, the trustee sought termination and immediate distribution to the ultimate beneficiaries.

Termination was denied on the ground that making loans to young artificers was not Franklin's sole purpose. He contemplated gifts to the city and state on the two hundredth anniversary of the fund. The highest court in Massachusetts was not convinced that his objective had ceased to be reasonable and in accord with the public interest. 26

Opinions can reasonably differ on the result reached in.Franklin Foundation v. Attorney General, and that is just the point. Judges contemplating the validity of a gift arguably charitable ought not to assume that termination of a directed accumulation and dissolution of the trust are automatic when evidence of obsolescence appears. The burdens of proof and persuasion are on those seeking to end the institutional machinery at work. Overcoming the

24340 Mass. 197, 163 N.E.2d 662 (1960).

25 Id. at 201, 163 N.E.2d at 666.

26 'Ben Franklin's will has been modified, and a loan fund of $\$ 1,735,549$ made available again .... Intended for young 'married artificers,' the loans will now be made to medical students and to secondary school graduates seeking further training in technical sciences and crafts." Foundation News, July 1962, p. 11.

Franklin's notions on the possibilities of mandatory accumulation have found modern exponents. A wealthy New York lawyer set up some one hundred inter vivos trusts with total assets of about $\$ 7$ million. Seven of the trusts with an accumulation provision were to run 500 to 1,000 years. N.Y. Times, July 16,1961, p. 1, col. 2; Newsweek, July 31, 1961, p. 69. The United States in tax suits succeeded in getting five of the seven declared invalid, but the two remaining-of which the ultimate beneficiary was the Commonwealth of Pennsylvania-successfully withstood attack. Holdeen v. Ratterree, 292 F.2d 338 (2d Cir. 1961). 
natural reluctance to interfere with a testamentary scheme is a greater task than generally realized.

\section{The Cy Pres Doctrine}

A factor related to perpetual life is administration of the cy pres doctrine which, on a finding of a general charitable intention in the donor, permits applying charitable funds to new objects when the original charitable purpose is, or becomes, impossible or inexpedient of fulfillment.27 But blackletter statements of the law of cy pres are misleading if taken as descriptions of what does occur in the life of charitable trusts rather than what may or should occur if legal principles are promptly and uniformly applied. Charitable gifts frequently are personified, particularly if they persist for any appreciable length of time. Their termination or modification is no more likely to proceed logically and efficiently than is the retirement of an old employee whose severance is not dictated by arbitrary rule.

Consider, for example, the lethargy revealed in Petition of Pierce.28 The testator, who died in 1870, directed that after the deaths of his widow, his mother, and his brother, his estate "be appropriated to the founding of a home for indigent seamen, and I authorize ... my executor to invest the said property and the income thereof and to use... the same in such manner as will do the most good to the class of indigent seamen." 29 The inventory showed that the entire value of the estate was 1,500 dollars. In 1912 the heirs-at-law attacked the intended charitable gift as indefinite and impossible of performance, but the Supreme Court of Maine upheld the bequest and directed that a decree be entered in accordance with its opinion. None was prepared and the estate was forgotten for twenty-five years.

Part of the estate consisted of a certificate of corporate stock which increased in value to such an extent that in 1937 a trustee was appointed to carry out the purposes of the trust. He resigned, and in 1944 a successor trustee was appointed. In 1954 the successor trustee sought instructions on disposition of income. In July, 1956, she was directed to distribute 10,000 dollars, but inasmuch as, after such expenditure, over 100,000 dollars of accumulated income remained undistributed, she forthwith sought a new construction of the will and instructions concerning administering the fund under the cy pres doctrine. The heirs-at-law claimed a resulting trust of the undistributed fund. In upholding the gift, the Supreme Court of Maine used alternative grounds. First, as a matter of construction the term "seamen" was not necessarily used by the testator to describe mariners of the type manning vessels like that he captained. That being so, beneficiaries of the trust need not be restricted to the extent assumed by all interested parties. Second, the testator had a general charitable intention to benefit "that wider group of men whose

274 SCOTT $\S 399$.

28153 Me. 180,136 A.2d 510 (1957).

29 Id. at 183,136 A.2d at 512-13. 
major means of livelihood was gained from the sea" and cy pres could be invoked to enlarge the class of beneficiaries. ${ }^{30}$

A more celebrated example of the cy pres doctrine in operation is Thatcher v. City of St. Louis. 31 There the testator, a bachelor who died in 1851 , left one-third of his estate in trust to "constitute a fund to furnish relief to all poor immigrants and travelers coming to St. Louis on their way ... to settle in the West."32 Heirs of the testator sought termination on the grounds that there were no longer beneficiaries of the class contemplated by the testator, that he had had no general charitable intention, and that there was a resulting trust by operation of law. Both the trustee and the Attorney General sought application of cy pres.

In generally affirming the decree applying cy pres, the Supreme Court of Missouri in 1934 noted a lower court finding that the "number of immigrants and travelers provided for by the will . . . is not so large as in former years ... but is not likely to cease altogether . . .,"33 that administrators of the fund had "determined to help all persons in need of aid or assistance, regardless of the direction from whence they came or where they were going ..."34 and that "as a matter of fact, every conceivable ailment or desire that was human in nature was considered a cause for assistance ... and within the terms of the... will....'35 Here the cy pres doctrine afforded relief-but much too late. Modification of the terms of the trust had been sought unsuccessfully as early as 1902,36 when it had been clear for some years that expenditures for administration had far outstripped those made for the relief of poor immigrants and travelers.

Both Petition of Pierce and Thatcher v. City of St. Louis show the application of the cy pres doctrine in poorest light. But comparable cases are not difficult to find; and our information on charitable wealth being scant, we simply do not know how representative they are.

\section{Surcharge}

A trustee who commits a breach of trust is personally liable to the beneficiaries for losses sustained because of his wrongful conduct.37 Put more elliptically, he may be surcharged. The trustee of the charitable trust certainly

30 Id. at 199,136 A.2d at 521 .

31335 Mo. 1130, 76 S.W.2d 677 (1934).

32 Id. at 1136,76 S.W.2d at 678.

${ }^{34} I d$. at 1139,76 S.W.2d at 680.

${ }^{33} \mathrm{Id}$. at 1136,76 S.W.2d at 678.

35 Ibid.

36 City of St. Louis v. Crow, 171 Mo. 272, 71 S.W. 132 (1902). From 1860 to 1898, out of an income to the trust of nearly $\$ 950,000$, only about $\$ 212,000$ was spent for the relief of "poor emigrants and travelers" and the balance was consumed in administration. $I d$. at $275,71 \mathrm{~S} . \mathrm{W}$. at 132 .

372 ScoTr § 205. 
is not explicitly exempted from the application of this general rule; on the contrary, the liability of the trustee of the charitable trust is frequently assumed, and the controversy centers on identifying proper parties plaintiff to enforce the trust. 38

There are, however, cases indicating that the rule on surcharge is not applied with customary force in the charitable trust cases. In Johnson Estate 39 the testator devised his home on South Broad Street, Philadelphia, Pennsylvania, to the City of Philadelphia to house the art collection he bequeathed to the City. He specifically directed that the art collection not be removed to any other place unless some extraordinary situation arose.

In 1921 the City sought court permission to sell the premises on South Broad Street and apply the proceeds of sale toward the cost of building a separate art gallery to house the collection. Permission was denied on the ground that no sufficient reason appeared to warrant deviation from the directions of the testator. By 1933 the cost of maintaining the makeshift gallery became prohibitive and the trustee without court permission moved the collection to a public gallery. The home of the testator thereafter was vacant.

As an incident to an accounting proceeding, the trustee in 1954 again sought permission to sell the South Broad Street property and apply the proceeds toward maintenance of the collection in a public gallery. The City joined in the petition in order to secure the site for the erection of a health center.

The opinion of President Judge Klein contains excerpts of testimony on the inadequacy of the makeshift gallery and the splendid facilities of the public gallery. Our concern here, however, is not with the convincing evidence of the testator's lack of foresight but rather with the flagrant disregard by the trustee of the supervisory function of the court: "This closing of the Broad Street residence and the removal of the collection to the Art Museum was made without the knowledge or approval of the orphans' court. This action was not only a clear violation of the city's contract with the executors . . . but was also in open defiance of Judge Gest's order." 40 The persons responsible for the illegal removal of the collection should be "censured." The request for approval of the sale of the South Broad Street property was denied. But not entirely. The City's representatives, having been informed during the course of the proceedings that the court would not sanction a sale, joined with the trustee in seeking permission to lease the South Broad Street site for a term of fifty years. Permission to lease, and to demolish the home of the testator and erect on the site a public health center, was granted. The art collection would remain at the public gallery.

The lesson of Johnson Estate is clear: The trustee of a charitable trust who

384 ScorT $\$ 391$.

3915 Pa. D. \& C.2d 407 (Orphans' Ct. 1958).

40 Id. at 425. 
is convinced of the desirability of a proposed course of action can with practical immunity commit a breach of trust. Restoration of the Broad Street residence by the trustee to the condition it would have been in had no breach of trust occurred was not required, and it is not likely to be where the property held in trust is of a quasi-public kind and there is no evidence of evil motive in the trustee who commits the breach. 41

The disinclination to apply the usual rule on surcharge is further evident in Bennet Estate. 42 The testatrix, who died in 1903, left her residuary estate of 277,000 dollars in trust "to found in the city of Wilkes-Barre, Pa., a home for poor little children, to purchase land to erect thereon a building suitable for that purpose and to furnish the same and to maintain it as a public charity ...."43 By 1933 corpus and accumulated income totaled more than 681,000 dollars. Sometime thereafter, and before 1940, the trustees expended nearly 149,000 dollars in building and equipping a brick cottage for children on land purchased from the Children's Home of Wilkes-Barre. In 1944 the trustees allegedly reported to the Orphans' Court that the main objective of the trust was "the maintenance and direction of the cottages for poor little children of this city and valley who are in need of a study and treatment for behaviour problems."44 From that time forward, trust funds were used to provide psychiatric treatment for problem children through a children's service center. As an incident to an accounting proceeding, an appointed guardian and trustee ad litem for "poor little children" unsuccessfully sought to surcharge the trustees for intentional deviation from the terms of the trust and a clear order of the court made in 1943 denying a request to apply the cy pres doctrine to the gift. In refusing to require that the trustees indemnify the trust for the expenditures improperly made, the court stressed the good faith of the trustees, the failure of the attorney general to object to their informal accounting, and his failure to join with the guardian in pressing for surcharge.

Neither Johnson Estate nor Bennet Estate articulates the notion that a trustee should be exempted from the operation of the usual rule on surcharge because the trust is charitable, but it is difficult to escape the inference that in both cases the trustees avoided surcharge for that reason. If exemption from the usual rule on surcharge in charitable trust cases is desirable, the creation of such an exception would seem a more appropriate task for the legislature than for the judiciary. At least a court, when weighing whether a charitable trust is in the public interest, ought to be skeptical about the efficacy of the surcharge as a device for future control.

41 "[W] period of time, the court may refuse to hold them liable." 4 ScoTT $\S 386$ at 2747.

4218 Pa. D. \& C.2d 595 (Orphans' Ct. 1959).

43 Id. at 597.

44 Id. at $602-03$. 


\section{III}

\section{A. The Conditioned Gift}

A gift undoubtedly charitable may be so conditioned that it gives pause to a court. In Connecticut College v. United States ${ }^{45}$ the testatrix, who died in 1955 , bequeathed 300,000 dollars to the United States on condition that within five years after her death the United States "will authorize to be built and will build on the West Point Military Reservation ... on a site south of Fort Clinton and North of the Bachelor Officers' Quarters on the general level of the Plain ... a memorial building or hall. ..."46 There was a residuary gift to Connecticut College "to be used to erect a dormitory or other building for the use of the College...." "47 In a suit for construction of the will, the United States pleaded that the contemplated site at West Point was not available and that the fund was insufficient to effect the intended purpose. The United States therefore requested that the fund be paid over to it to use for a purpose similar to that desired by the testatrix. Connecticut College argued that the particular purpose of the testatrix being unattainable, the 300,000 dollars passed as part of the residuary estate.

The district court acceded to the government's request, but the circuit court reversed and remanded to await a governmental decision accepting the bequest on the terms set by the testatrix or rejecting it altogether. A determination that the bequest created a charitable trust was not necessary to decision because carrying out the plan of the testatrix had not become impossible or impracticable so as to justify applying the cy pres doctrine: "[T] he cy pres doctrine does not authorize or permit a court to vary the terms of a bequest and to that extent defeat the intention of the testator merely because the variation will meet the desire and suit the convenience of the trustee." 48

Choosing a site for a permanent structure on public property is more than a matter of "convenience to the trustee." It is of course conceivable that the testator's choice of site will coincide with that made by those charged with the obligation of reconciling competing claims for limited space. But if the testator's choice is not "impossible," the government must rise to the bait or forego the bequest.

Testamentary directions like those of Connecticut College v. United States are found in Heinlein v. Elyria Sav. \& Trust Co.49 There the testator devised his residuary estate to a bank in trust for specified purposes including expending not to exceed 16,000 dollars

to convert the site of my homestead in a public park to be known as

'Wagner Brothers Park.' My ... trustee is further authorized ... to ... 45276 F.2d 491 (D.C. Cir. 1960).
$46 I d$. at 492.
47 Id. at 493.
48 Id. at 497.

4975 Ohio App. 353, 62 N.E.2d 284 (1945). 
dispose of any buildings ... and to beautify ... with suitable plantings ... good watering system, together with the necessary walks and shrubs. To install ... a very beautiful electric illuminated fountain .... There is to be no seats or benches, no drinking fountain and no rest rooms .... I desire constructed a stone wall seven (7) feet high by eighteen (18) inches thick along the entire east side of said park and also along the entire north side... so constructed that it may be flower covered, I prefer the everlasting statice flower of Florida $\ldots . .50$

Five first cousins of the testator were his next of kin. Three of them in a construction proceeding alleged invalidity of the trust and sought the residuary estate by way of resulting trust. The City of Elyria, Ohio, where the land was located, asked application of cy pres to allow it to use the gift to care for a municipal park.

The Ohio Court of Appeals conceded that the park would be in an unattractive location, but argued that "the more sordid a locality, the greater is the contrast of beauty." 51 The testamentary prohibition of benches, drinking fountains and rest rooms, on the one hand, and the required erection of a flower-covered stone wall, on the other, were not alluded to in the opinion sustaining the trust, unless the parenthetical_-"as to minor details, discretion is vested in the trustees of a charitable trust to so execute such trust, as not to transgress the law, or to contravene established public policy" 52 -be treated as a guide to reconciling egocentric testamentary directions with full beneficial use by the public.

\section{B. The Future Gift}

If the enjoyment of a disputed gift is by the terms of the will deferred for an appreciable length of time, the court determining validity might well consider the likelihood that the need envisaged by the testator will exist when the gift is expended. In Matter of Scott, 53 for example, the testator, who died in 1912, upon the death of life income beneficiaries and in default of lineal descendants, gave a remainder "to the Rector, Church Wardens and Vestrymen of St. Thomas' Church in the City of New York, for the purpose of erecting and maintaining, in such place as they may select, a building or buildings for the care of persons suffering from tuberculosis, to be called the Scott Memorial Home."'s4 Apparently more than forty years elapsed before the remainder became payable, and by that time sanitariums for tuberculars

$50 \mathrm{Id}$. at 356,62 N.E.2d at 286.

s1 $I d$, at 362,62 N.E. $2 d$ at 289 .

$52 I d$. at 361,62 N.E.2d at 288 . For a case in which the desire to influence conduct through the testamentary conditional gift to charity was particularly evident, see Fidelity Union Trust Co. v. Egenolf Day Nursery Ass'n, 64 N.J. Super. 445, 166 A.2d 402 (Ch. 1960).

538 N.Y.2d 419, 171 N.E.2d 326, 208 N.Y.S.2d 984 (1960).

54 Id. at 423,171 N.E.2d at 327,208 N.Y.S.2d at 987. 
were being abandoned because the number of patients had declined and methods of treatment had changed. The church argued that the gift to it was absolute or, alternately, that the court should, by applying the cy pres doctrine, approve dispositions for predominantly church purposes, namely, improving the building, placing a Scott memorial plaque at an entrance, and holding the balance of the principal $(1,600,000$ dollars $)$ for maintenance and general charitable purposes. The New York Surrogate responded by directing that the entire fund be used for the care of persons suffering from respiratory and thoracic diseases, 55 and his disposition of the case was approved by the Appellate Division without opinion. ${ }^{56}$ The Court of Appeals reversed and remanded, saying:

We agree with the Attorney-General ... that the original contention of St. Thomas Church is invalid that it has absolute power to use this remainder for any corporate purpose, and likewise that its proposal was unjustified to devote almost all of these funds by cy pres to the church building. Nevertheless it does not follow that none should be expended on this edifice, since we are persuaded that the testator was concerned among other matters with attaching his family name... to a building ... maintained by St. Thomas Church. ${ }^{57}$

In Matter of Scott futurity of the gift to charity combined with relative narrowness of purpose to cause difficulty when the course of events permitted enjoyment of the gift. The relevance of futurity in the questionable case varies directly with the particularity of the charitable purpose. The court should be reluctant to uphold the deferred gift when the testator departs from highly generalized language in attempting his gift.

\section{IV}

\section{A. Identity of Competing Claimants}

The preceding cases delineated attributes of many charitable gifts that should be treated as relevant by a court considering the validity of a doubtful gift. Frequently, however, a factor that is unquestionably relevant to decision receives somewhat unwarranted emphasis. The degree of consanguinity between the testator and those competing with the public for the disputed gift is alluded to in case after case and may indicate a judicial attempt to modify the law of intestate succession. In Wilber $v$. Owens ${ }^{58}$ the testator, who died in 1945 , attempted59 to leave 150,000 dollars in trust to use the income to complete and publish his "Random Scientific Notes Seeking the Essentials in

55 In the Matter of Estate of Scott, 19 Misc. 2d 18, 189 N.Y.S.2d 87 (Surr. Ct. 1959).

56 Matter of Scott, 10 App. Div. 2d 556, 196 N.Y.S.2d 597 (1960).

57 Matter of Scott, 8 N.Y.2d 419, 428, 171 N.E.2d 326, 330, 208 N.Y.S.2d 984, 990 (1960).

582 N.J. 167, 65 A.2d 843 (1949).

59 "As it turned out, the bequest was far in excess of the value of his estate." Id. at 172, 65 A.2d at 845 . 
Place and Space." Although the vice-chancellor of New Jersey found that the notes should not be published inasmuch as they were irrational, unintelligible, and scientifically valueless, he nevertheless found a general charitable intention justifying the application of the cy pres doctrine-and this though the testator set up six alternative legatees in order to assure effectuation of his particular intention. ${ }^{60}$ In affirming the decree of the vice-chancellor, the Supreme Court of New Jersey mentioned that the testator "had no kin nearer than first cousins." 61

The reluctance to allow the statute of descent and distribution to operate normally is more manifest in Estate of Rollins.62 By the residuary clause of her holographic will the testatrix directed that property go "to some charitable institution, or research fund, or for a suitable memorial to my mother and father (no statue or monument)." 63 The will having been executed less than six months before death, not more than one-third of the estate could go to charity in any event, ${ }^{64}$ but the heirs argued that the gift failed altogether because the residuary clause did not limit the bequest to purposes wholly charitable and did not designate a class of charitable beneficiaries or name someone to make such a selection. The California Court of Appeal conceded that if the testamentary language permitted non-charitable as well as charitable uses, the gift failed; but the problem being one of construction, only the phrase "a suitable memorial to my mother and father" created any appreciable doubt, and that was dispelled by the qualifying parenthetical "(no statue or monument)." For "once a statue or monument is excluded, it is difficult to conceive of a "memorial' which is not a charitable use."65

Difficult, perhaps, but not remarkably so.66 Perhaps equally significant to the result were the following excerpts from the opinion:

Decedent's will makes specific mention of all the heirs at law-those who would take the residue if the charitable bequest is invalid. Decedent's sole surviving sister is left $\$ 15,000$, plus Oklahoma property. The will also leaves $\$ 500$ each to four nieces and nephews, children of deceased sisters ... . There are two nephews to whom no cash bequest is made, but the will states "All other possible heirs are able-bodied and wage earners,"

60 Wilber v. Asbury Park Nat'l Bank \& Trust Co., 142 N.J. Eq. 99, 59 A.2d 570(Ch. 1948).

61 Wilber v. Owens, 2 N.J. 167, 175, 65 A.2d 843, 846 (1949).

62163 Cal. App. 2d 225, 328 P.2d 1005 (1958).

$63 \mathrm{Id}$. at $227,328 \mathrm{P} .2 \mathrm{~d}$ at 1006.

64 CAL. PRob. Code $\S \S 41,43$ (1931).

65163 Cal. App. 2d at 229, 328 P.2d at 1008.

${ }^{66}$ Suppose the testatrix had left her residuary estate to her country club "to be used for a suitable memorial to me (no statue or monument)" ? In Deichelmann Estate, $21 \mathrm{~Pa}$. D. \& C.2d 659 (Orphans' Ct. 1959), a testamentary bequest of $\$ 5,000$ to the "Hanna Penn House" (an organization of Republican women of Pennsylvania having as its purpose the creation of a center of education and information on political subjects and the promotion of participation in political activities) was held noncharitable, valid and unaffected by the mortmain act. PA. STAT. ANN. tit. 20, § 180.7(1) (1950). 
and an intent to limit participation by all the heirs is shown by the sentence "If any one contests this will I give any such persons $\$ 5.00 . " 67$

Because of the [mortmain act], the intent of the testatrix can be given effect only as to a third of her estate. Respondents here have therefore taken to an extent clearly contrary to the intent of the testatrix. In the light of the applicable canons of construction, we cannot construe the will to bestow still further benefits upon these unintended beneficiaries. 68

Invalidating an intended testamentary gift frequently results in a windfall to heirs or next of kin only remotely related to the decedent. If distaste for that fairly common phenonemon is widespread, 69 the remedy lies in amending the statute of descent and distribution to make the state a beneficiary when immediate kin are lacking.

\section{B. Sum at Stake}

In close cases the costs of validation and supervision may far outweigh any benefit that the public will receive from the purportedly charitable gift. The testatrix in Lippincott Estate 70 died in 1932 leaving her residuary estate in trust to use the annual income "for the purpose of paying entrance fees into homes and institutions for the blind or other homes in ... Pennsylvania, of persons qualified as hereinafter provided ...."71 The trustees were authorized by the will to advertise periodically for applicants and were directed to notify "all organizations within ... Pennsylvania interested in ... relief of the blind as to the function of the Fund ...."72 Income not expended in paying entrance fees was to be used to start the blind in business "the amounts advanced ranging from a minimum of fifty dollars $(\$ 50)$ to a maximum of three hundred dollars ( $\$ 300)$ per person.'"73

67163 Cal. App. 2d at 228-29, 328 P.2d at 1008.

68 Id. at 230,328 P.2d at 1008.

${ }^{69}$ The reluctance to permit remote heirs and next of kin to take in the borderline case is manifest in Howard Savings Institution v. Peep, 34 N.J. 494, 170 A.2d 39 (1961). The testator, who died in 1957, left $\$ 50,000$, as well as his residuary estate, to Amherst College in trust "to be used as a scholarship loan fund for deserving American born, Protestant, Gentile boys of good moral repute, not given to gambling, smoking, drinking or similar acts." Id. at 497, 170 A.2d at 41. Amherst declined to accept the fund unless the ProtestantGentile restriction was eliminated. The Supreme Court of New Jersey agreed with the Chancery Division that the testator had a general charitable intention, that the doctrine of cy pres could be invoked, and that the distasteful restriction could be stricken from the will. Both courts stressed the degree of kinship of the claimants under the statute of descent and distribution: "The testator had no close relatives. He left no spouse or descendants or parents or brothers or sisters. His surviving kin are two cousins and a cousin of his mother. These persons lived distant from testator's home, and there is no evidence that he had any personal contact with them." Id. at 505, 170 A.2d at 45.

A provision in the will for those competing with the public for the disputed gift may justify defeating the attempts of the heirs to gain a substantial sum. See First Nat'l Bank v. Stevenson, 293 S.W.2d 362 (Sup. Ct. Mo. 1956).

7017 Pa. D. \& C.2d 80 (Orphans' Ct. 1959).

$71 \mathrm{Id}$. at $81 . \quad 72 \mathrm{Id}$. at $82 . \quad 73 \mathrm{Id}$. at 83. 
As an incident to an accounting proceeding, a trustee petitioned for discharge, appointment of a substitute trustee and modification of the terms of the trust. In disposing of the petition, the court said:

This case furnishes a classic example of the problems which arise when nobly inspired but impecunious testators create grandiose and wholly impractical trusts with their limited funds. The principal of this trust had a value of approximately $\$ 5,000$ when it was received by the trustees in 1933. Through prudent management, and with the assistance of the surging inflationary pressures which have engulfed our nation's economy, its value has increased to about $\$ 17,000$. Even this enhanced corpus would have been much too small 25 years ago to warrant the creation of the ambitious plan contemplated by decedent. Today, with the drastically reduced purchasing power of the dollar, it is woefully inadequate.

When we consider the many responsibilities placed upon the trustees in administering this small trust, its impracticability comes into sharp focus. The average income which this fund can be expected to produce is approximately $\$ 750$ a year. The trustees' joint compensation for administering the trust would be about $\$ 37.50$ annually. With these miniscule earnings, and for this negligible compensation, they are expected to carry out the ambitious program defined by testatrix. 74

The difficulty in Lippincott Estate is initial and continuing impracticability. If obvious in 1959, why not in 1932 ? Given both the propensity of testators to overestimate the extent of their wealth and the reluctance of courts to depart from testamentary directions, the small gift in the doubtful case should fail. It does not follow that the large gift in a questionable case should be confirmed; but we should frankly recognize that de minimis applies to charitable giving.

\section{CONCLUSION}

Reformers of the law of charitable trusts seek legislation which would require reporting to the attorney general, liberalization of the cy pres doctrine and adequate supervision of the creation, maintenance and expenditure of charitable funds. ${ }^{75}$ Pending such legislative changes, what should a court do when faced with the questionable gift?

First, a court quick to cut off the grasping heirs might well remember that at least they are among the living. True, they may squander their unearned wealth rather than devote it to posterity in perpetuity, but if we were truly shocked by the spectacle of the laughing heir, we would enact appropriate remedial legislation. ${ }^{76}$ Bloodline roulette may not appeal to political and social

$74 \mathrm{Id}$. at 84-85.

75 Karst, The Efficiency of the Charitable Dollar: An Unfulfilled State Responsibility, 73 HARv. L. Rev. 433 (1960).

76 Disqualifying remote relatives from succeeding to the property of a decedent is the simplest remedy. Atkinson, Succession Among Collaterals, 20 Iowa L. Rev. 185, 195 (1935); Cavers, Change in the American Family and the "Laughing Heir," 20 IowA L. REv, 203, 212 (1935). 
reformers, but it has not proved an anathema to legislators, and in that regard they may be closer to the public pulse than the more sophisticated would like to believe. In any event, we can reason with the living who dispose of their wealth, but the dead are beyond persuasion; and once we have indulged them, we may be centuries shaking them off.

Second, a court can take account of the need for quasi-public wealth in the community, particularly if the purpose contemplated by the testator is highly restrictive. Certainly if need is non-existent, the questionable gift is not in the public interest, and it is public interest that justifies the charitable gift. A doubtful gift to "charity" is more tractable in the long run"7 than is the gift to supply "footwear to present and future members of said [Actors Equity] Association and of the Chorus Equity and to all needy actors of the theatrical profession ... who can't buy shoes ...."78 What is "charitable" will change with time;79 but there is general agreement that from time to time certain kinds of activities clearly qualify, and diversion of funds to them from the unrestricted charitable gift can properly be made with a minimum of inconvenience.

Third, judges can take account of all other facts relevant to decision, including the sum at stake, the likelihood of abuse by the successors in interest of the testator, the continuing impact of any conditions attached to the gift, the probable effective life span of the trust, the existence and duration of a directed accumulation, futurity as opposed to immediacy of enjoyment, and the identity of competing claimants. These facts are, of course, alluded to and weighed in current opinions; but there is in them a discernible tendency to obscure the influence of circumstances perhaps critical to decision, to fail to project the questionable gift through time to determine its utility and to bury the adjudicative process in a welter of definitions and quotations from inept precedents that are of no help in solving the problem at hand.

Finally, courts can continually appraise the function of charitable wealth in a changing society. As compulsory inter vivos arrangements for the care

77 E.g., in Druker v. Levy, 262 S.W.2d 681 (Ky. Ct. App. 1953), the testatrix gave her residuary estate "to my Executors hereinafter named, to be distributed by them to such Jewish charities and organizations or institutions, as may be selected by [two designated persons]." The niece and sole heir of the testatrix contended invalidity because the language did not require that a charity be selected as beneficiary. In upholding the gift the highest court of Kentucky said: "The word 'and' in this quoted phrase is the key to its correct interpretation. In our opinion this phrase requires the trustees to select one or more institutions or organizations that are also Jewish charities. We think the phrase must be interpreted as reading "Jewish charitable organizations or Jewish charitable institutions." " Id. at 682.

78 Guaranty Trust Co. v. New York Community Trust, 141 N.J. Eq. 238, 56 A.2d 907, aff'd, 142 N.J. Eq. 726, 61 A.2d 239 (1948). The testator left $\$ 250,000$ for the stated purpose. Andrews, Bounty from Beyond: How to Give the Most Good with Your Bequests, Harper's, Aug. 1962, p. 65.

794 Scort $\S 368$. The Nathan Report, presented to the English Parliament in 1952, recommended a new definition of charity. Charitable Trusts Committee, Report, CMD. No. 8710, at 36 (1952). No explicit definition was included in the Charities Act of 1960. Marshall, The Charities Act (1960), 24 MoD. L. REv. 444 (1961). 
of dependents and successors become commonplace,, 80 and as administrative machinery for the supervision of quasi-public funds becomes more efficient, a more indulgent view of the questionable gift can safely be taken.

It will not do to say that the decision rests with the dead, however much we may have respected them in life and revere them in memory. And blackletter law does not dictate the result, for what is "charitable"81 is a flexible notion requiring application to the information at hand. The decision in the close case rests with the judge. Freed from catchwords, unaffected by bias and afforded as much relevant information as possible consistent with getting the work done, he can make the characterization "charitable" consonant with "in the public interest."

${ }^{80}$ Lynn, Foreman \& Wehr, The New Inheritance: Employee Benefit Plans as a Wealth Devolution Device, 11 Stan. L. Rev. 242 (1959).

81 Keeton, Social Change in the LaW of Trusts 80 (1958). 